To cite this article: Kılıç EK, Demircan ŞA, Hatipoğlu ÇA, Arslan K, Bulut C, Cesur S, Kınıklı S. Bir eğitim ve araştırma hastanesinde takip edilen Hepatit B ile enfekte gebelerin değerlendirilmesi. Turk J Clin Lab 2020; 1: 13-17.

\title{
Bir eğitim ve araştırma hastanesinde takip edilen Hepatit B ile enfekte gebelerin değerlendirilmesi
}

\section{Evaluation of hepatitis $b$ infected pregnants followed at a research and training hospital}

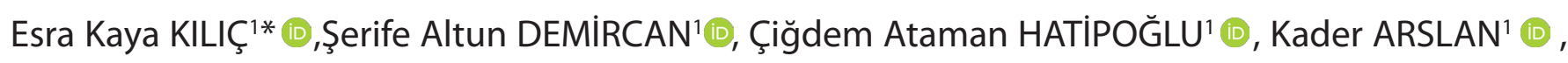 \\ Cemal BULUT2' Salih CESUR' Sami KINIKLI'
}

1 Sağlık Bilimleri Üniversitesi Ankara Eğitim ve Araştırma Hastanesi Enfeksiyon Hastalıkları ve Klinik Mikrobiyoloji Kliniği, Ankara/TÜRKiYE

²Sağlık Bilimleri Üniversitesi Gülhane Eğitim ve Araştırma Hastanesi Enfeksiyon Hastalıkları ve Klinik Mikrobiyoloji Kliniği, Ankara/TÜRKiYE

\section{Öz}

Amaç: Kronik hepatit B önemli bir sağlık sorunudur. İmmünoprofilaksiye rağmen, anneden çocuğa hepatit B virüs (HBV) bulaşı yüksek oranda viremi olan annelerin \% 1-10' unda görülür. Gebelerin bu nedenle HBsAg pozitifliği yönünden taranması ve takibi önerilir. Bu çalışmada kliniğimizde izlenen hepatit B ile enfekte gebe kadınların yönetimi ve tedavisi değerlendirildi.

Gereç ve Yöntemler: Çalışmaya 85 HBV ile enfekte gebe dahil edildi. Gebeler, gebelik süresince ve doğum sonrasında periyodik olarak takip edildi. Üç aylık aralıklarla hastaların HBV-DNA ve karaciğer fonksiyon testleri değerlendirildi.

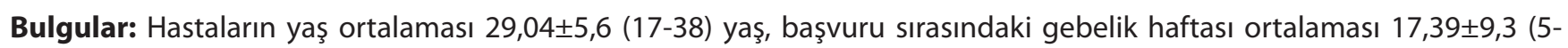
38) idi. Hastaların $14^{\prime}$ ü $(\% 16,4)$ gebelik sırasında yapılan taramalarla HbsAg pozitif olduğunu öğrendi. Gebelerin $25^{\prime}$ inde $(\% 29,4)$ Anti-HAV IgG pozitifti. Onüç hastaya $(\% 15,3)$ antiviral tedavi başlandı. Onüç $(\% 15,3)$ hastaya tedavi başlandı, tedavi başlanan hastaların 12' si $(\% 92,3)$ tenofovir disoproksil fumarat alırken, bir hasta telbivudin almaktaydı. Hiçbir hastada tedaviye bağlı yan etki gözlenmedi. Bebeklerin doğum sonrası takiplerinde antiviral tedavi ile ilişkili problemler izlenmedi. Takibi yapılabilen $25(\% 29,4)$ bebeğin hiçbirinde HbsAg pozitifliği saptanmadı.

Sonuç: Hepatit B bulaşında önemli bir yol olan vertikal bulaşların engellenmesi için, gebelik taramalarının ve gebelerin yakın takibinin yapılması gerekmektedir.

Anahtar kelimeler: gebelik; yenidoğan; hepatit B; antiviral tedavi

Sorumlu Yazar*: Esra Kaya Kılıç Sağlık Bilimleri Üniversitesi Ankara Eğitim ve Araştırma Hastanesi Enfeksiyon Hastalıkları ve Klinik Mikrobiyoloji 


\begin{abstract}
Aim: Chronic hepatitis B is an important health problem. Despite immunoprophylaxis, hepatitis B virus (HBV) transmission from mother to child is seen in 1-10\% of mothers with high rates of viremia. Therefore, screening and follow-up of pregnant women is recommended for HBsAg positivity.
\end{abstract}

Material and Methods: In this study, the management and treatment of hepatitis B infected pregnant women were evaluated in our clinic. 85 HBV infected pregnant women were included in the study. The pregnant women were followed periodically during pregnancy and after delivery. HBV-DNA and liver function tests were evaluated at three-month intervals.

Results: The mean age of the patients was 29.04 \pm 5.6 years (range, 17-38 years), and the mean gestational age at admission was $17.39 \pm 9.3$ (5-38). 14 of the patients (16.4\%) learned that HbsAg was positive by screening during pregnancy. AntiHAV IgG was positive in 25 (29.4\%) of the pregnant women. Thirteen patients (15.3\%) underwent antiviral therapy. Thirteen (15.3\%) patients were started on treatment and 12 (92.3\%) patients received tenofovir disoproxil fumarate and one patient was receiving telbivudine. No side effect was observed in any patient. There were no problems about infants, associated with antiviral treatment in the postpartum period. There were no HbsAg positivity in 25 (29.4\%) infants.

Conclusion: In order to prevent vertical transmission, which is an important pathway in the transmission of hepatitis B, it is necessary to follow up pregnancy screenings and pregnant women closely.

Key words: Pregnancy; newborn; hepatitis B; antiviral treatment

\section{Giriş}

Hepatit B karaciğeri enfekte ederek, akut ve kronik enfeksiyona neden olan ve hayatı tehdit eden viral bir enfeksiyondur. Global bir sağlık problemi olarak yaklaşık 257 milyon insanı etkilemiş ve 2015 yılında 887000 ölüme neden olmuştur. Hepatit B prevelansı World Health Organization (WHO) Africa Bölgesinde en yüksek \%6,2 iken, WHO Doğu Akdeniz, GüneyDoğu Asya ve Avrupa bölgelerinde prevelansı sırasıyla \%3,3, $\% 2,0$ ve \%1,6 olarak saptanmıştır (1). Bu oranlar Hepatit B enefeksiyonun neden global bir sağlık problemi olduğunun göstermektedir.

Önemli bulaş yollarından biri maternal geçiştir. Anne HbeAg pozitif ise doğum sonrasında bebek için kronik enfeksiyon gelişme ihtimali \%80-90' dur (2). Aşı ile önlenebilen ancak enfekte olunduğunda kronikleşen bu hastalık için 1980' li yılların başından bu güne kadar etkili ve güvenilir bir HBV aşısı mevcuttur $(3,4)$. Bu bağlamda, WHO önerisi ile hepatit $B$ ile enfekte anneden doğan bebeklere standart hepatit $B$ immunglobulini ve hepatit $B$ aşısı doğumdan hemen sonraki 12 saat içinde ve takip eden 2 . ve 6 . aylarda iki doz uygulaması ile bebeğe immunizasyon yapılır. Standart aşı ve immunglobulin uygulamaları ile maternal bulaşın engellenmesinde \%95 etkinlik bildirilmesine rağmen yüksek viremik annelerden doğan bebeklerde \%8-30 oranında aşı başarısızlığı saptanmıştır (5). Annenin yüksek viremi düzeyi, intrauterin enfeksiyon ya da HBV yüzey proteinindeki mutasyonlar immunoproflaksideki başarısızlıkların nedeni olarak sayılabilir $(6,7)$. Bu nedenlerle gebelik süresince HbsAg pozitif bireylerde HBV-DNA ve karaciğer fonksiyon testlerinin düzenli takibi önerilir. Gebelik döneminde verilen antiviral tedavinin esas amacı, annenin hepatik fonksiyonlarını kontrol altında tutmak ve bebeğe Hepatit B virus bulaşını engellemektir (8). Lamivudin, telbivudin ve tenofovir tedavilerinin bulaşı azalttığını ve güvenilir olduğunu gösteren çalışmalar mevcuttur (9, 10, 11). Gebelerde viral yükün yüksek olması (>108 kopya/mL veya $2 \times 107 \mathrm{IU} / \mathrm{mL}$ ) anneden bebeğe HBV geçiş rikini artırmaktadır. Viral yükün 2×105 IU/ $\mathrm{ml}$ ve $2 \times 107 \mathrm{IU} / \mathrm{mL}$ aralığında olması durumunda bulaş riski düşüktür (12). Ancak American Association for the Study of Liver Diseases (AASLD) tedavi başlama önerisi viral yükün $>2 \times 105 \mathrm{IU} / \mathrm{mL}$ olduğu durumlardır (13).

Bu çalışmada amacımız kliniğimizde takip ve tedavi edilen hastalrın epidemiyojik verilerini ve vertikal bulaşta antiviral ajanların etkinliklerini değerlendirmektir.

\section{Gereç ve Yöntemler}

Şubat 2012-Ağustos 2018 yılları arasında HbsAg pozitifliği bilinen ya da yeni saptanan gebelerin verileri resrospektif olarak incelendi. Kliniğimizde $\mathrm{HbsAg}$ pozitifliği nedeni ile takipli iken gebe kalan ve obstetrik polikliniğince $\mathrm{HbsAg}$ pozitifliği saptandıktan sonra kliniğimize yönlendirilen 113 hasta tespit edildi. Gebeliği süresince birden fazla kere enfeksiyon hastalıkları polikliniğine kontrole devam eden 85 hasta çalışmaya dahil edildi. Hepatit C, Hepatit D, HIV koenfeksiyonu olanlar, bilinen kronik karaciğer hastalığı olanlar ve gebeliğin yağlı karaciğeri gibi gebelik komplikasyonu olan hastalar çalışmaya alınmadı.

Gebeler, gebelik süresince ve doğum sonrasında periyodik olarak takip edildi. Üç aylık aralıklarla hastaların HBV-DNA ve karaciğer fonksiyon testleri değerlendirildi. Hastaların başvuru sırasında Anti-Delta, Hbe Ag, Anti Hbe, Anti HAV IgG değerleri, yaş, gebelik 
sayısı, gebelik haftası, var olan çocukların HbsAg ve Anti-HBs durumları, HBV için tedavi alma hikayesi bilgileri kaydedildi.

Doğum sonrası hemen, yenidoğanların hepsine $0,5 \mathrm{~mL}$ Hepatit B immunglobulini tek doz ve $0,5 \mathrm{~mL}$ Hepatit B aşısı (24 saat içinde) intramuskuler yolla uygulandı. Ulusal aşı takvimi uyarınca bebeklere 1. ve 6. aylarda Hepatit B aşısı önerildi. Üçüncü doz Hepatit $B$ aşısından sonra maternal geçişi değerlendirmek amacı ile $\mathrm{HBsAg}$ ve AntiHbs tetkikleri istendi.

İstatsitiksel analizler SPSS 20.0 paket programı kullanılarak, kategorik değişkenler sayı ve yüzde verilerek değerlendirildi.

\section{Bulgular}

HbsAg pozitif olan 85 hasta çalışmaya alındı. Hastaların yaş ortalaması 29,04 $\pm 5,6$ (17-38) yaş, başvuru sırasındaki gebelik haftası ortalaması 17,39 $\pm 9,3$ (5-38) idi. Üç $(\% 3,5)$ hastada HbeAg pozitifti. Anti-Hbe pozitif hasta sayısı $46(\% 54,1)$ idi. Gebelerin $25^{\prime}$ inde $(\% 29,4)$ Anti-HAV lgG pozitifti. Hastaların demografik özellikleri tablo 1'de gösterilmiştir.
$(\% 92,3)$ tenofovir disoproksil fumarat alırken, bir hasta telbivudin almaktaydı. Anti viral tedavi başlanma haftasının ortancası 20,6 \pm 9,2 hafta idi. Tedavi başlanan gebelerin hiçbirine 28 haftadan daha sonra tedavi başlanmadı. Doğum sonrası her bebeğe Hepatit B aşısı ve immunglobulin birlikte uygulandı. Anti viral tedavi alan gebelerin trimesterlerine göre HBV-DNA değerleri tablo 2' de gösterilmiştir.

Tedavi alan hastaların birinde $(\% 7,7)$ HbeAg pozitifken, $12(\% 92,3)$ hastada AntiHbe pozitifti. Bu gruptaki hastalrın ALT ortancası 116,8 \pm 298 ,2 (min 10-max 1056) olarak belirlendi. Tedavi almayan grubun ALT ortancası 18,8 \pm 6,34 (min 8-max 33) idi.

Anti viral tedavi başlamayan gebelerin başlangıçta HBV-DNA ortancaları 797,17 IU/mL (min 0-max 5472) idi. Bu hastaların trimesterlere göre HBV-DNA değerleri tablo 3'te özetlenmiştir.

Hastaların hiçbirinde ilaçlara bağlı yan etki gözlenmedi. Gebelik süresince antiviral tedaviyi tolereedemeyen bir hasta tedaviyi bıraktı. Doğum sonrası kontrollerine devam eden $25(\% 29,4)$ hastanın 12' sinin $(\% 14,1)$ bebeğinde Anti HBs pozitifliği saptandı, diğerlerinin hepatit serolojisi bilgilerine ulaşılamadı. Gebelik süresince antiviral

\begin{tabular}{lllll}
\hline \multicolumn{1}{l}{ Tablo 1. Hastaların demografik özellikleri } & Minimum & Maksimum & Ortanca & Std. Deviasyon \\
\hline Yaş & 17 & 38 & 29,04 & 5,634 \\
\hline Gebelik haftası & 5 & 38 & 17,39 & 9,384 \\
\hline Başlangıç HBV-DNA (IU/mL) & 0 & 327343730 & 8431741,58 & 52410920,102 \\
\hline ALT & 8 & 1056 & 52,03 & 176,213 \\
\hline Doğum sonrası HBV-DNA (IU/mL) & 0 & 9612 & 1810,68 & 3309,779 \\
\hline Doğum sonrası ALT (IU/L) & 14 & 42 & 24,73 & 9,382 \\
\hline ALT: alaninamino transferaz & & & & \\
\hline
\end{tabular}

\begin{tabular}{llllll}
\hline \multicolumn{1}{l}{ Tablo 2. Antiviral tedavi alan hastaların viral yüklerinin } & gebelik öncesi, gebelik sırasında ve doğum sonrasındaki dağılımı \\
& Minimum & Maksimum & Ortanca & Std. Deviasyon \\
\hline Başlangıç HBV-DNA (IU/mL) & 0 & 327343730 & 25293730,85 & 90755166,243 \\
\hline İkinci trimester HBV-DNA (IU/mL) & 9450 & 1468053 & 738751,50 & 1031388,072 \\
\hline Üçüncü trimester HBV-DNA (IU/mL) & 20 & 6075549 & 1283570,20 & 2680890,524 \\
\hline Doğum sonrası HBV-DNA (IU/mL) & 0 & 6402 & 2473,00 & 3093,153 \\
\hline
\end{tabular}

\begin{tabular}{llllll}
\hline \multicolumn{1}{l}{ Tablo 3.Antiviral tedavi almayan hastaların viral yüklerinin gebelik öncesi, gebelik sırasında ve doğum sonrasındaki dağılımı } \\
& Minimum & Maksimum & Ortanca & Std. Deviasyon \\
\hline Başlangıç HBV-DNA (IU/mL) & 0 & 5472 & 797,17 & 1433,407 \\
\hline İkinci trimester HBV-DNA (IU/mL) & 0 & 2666 & 512,83 & 983,702 \\
\hline Üçüncü trimester HBV-DNA (IU/mL) & 0 & 3114 & 515,40 & 1032,677 \\
\hline Doğum sonrası HBV-DNA (IU/mL) & 0 & 9612 & 1664,17 & 3894,267
\end{tabular}

Gebelerin diğer çocuklarındaki HbsAg pozitifliklerine bakıldığında, sadece iki annenin, iki çocuğunda HbsAg pozitifliği olduğu belirlendi. Hastaların 14' ü $(\% 16,4)$ gebelik sırasında yapılan taramalarla HbsAg pozitif olduğunu öğrenmişti.

Hastaların 25'i $(\% 29,4)$ doğum sonrası kontrole geldi. Onüç $(\% 15,3)$ hastaya tedavi başlandı, tedavi başlanan hastaların 12 ' si tedavi alma durumu ile bebeklerinin AntiHbs pozitiflikleri arasında istatistiksel olarak anlamlı farklılık yoktu ( $p>0,01)$. Doğum sonrası ulaşılan bebeklerin hiçbirinde HBsAg pozitifliği saptanmadı. Takibi yapılabilen bebeklerin hiçbirinde erken doğum, düşük doğum ağırılığı, konjenital anomaliler ve renal disfonksiyon saptanmadı. 


\section{Tartışma}

Hepatit B virüsünün perinatal bulaşı özellikle hiperendemik bölgelerde yaygın bir bulaş yoludur. Geçmiş dekatta etkili antivirallerin kullanılması, üçüncü trimesterde viral supresyonun sağlanması ile de bulaş riski azaltılmıştır (12). Türkiye, HBV infeksiyonu için orta endemisiteli (\%2-8) bir ülkedir (14). Bu çalışmada HBV enfeksiyonu tanısı olan ya da gebelik sırasında tanısı konulan, antiviral tedavi alan ve almayan hastalar retrospektif olarak değerlendirildi.

Anneden bebeğe HBV bulaşı gebelik sırasında, doğumda, emzirme döneminde, doğum sonrasında ve bebeğin günlük bakımı sırasında olabilmektedir $(15,16)$. Takip ettiğimiz gebelerden ikisinde takibimizden önceki gebeliklerinden doğan iki bebekte HbsAg pozitifliği saptanmış. Bu durum vertikal bulaşta halen bazı yetersizliklerin olduğunu düşündürmektedir. Çalışmamızda takip edilen gebelerden ve doğum sonrası kontrollerine gelmeye devam ederek bilgilerine ulaşılan annelerin $12^{\prime}$ sinin $(\% 14,1)$ bebeğinde AntiHbs pozitif saptandı. Tüm gebelerin doğumları sırasında bebeklere immunglobulin ve hepatit $B$ aşısı uygulandı. Doğum sonrası takiplerde saptayabildiğimiz kadarı ile hiçbir bebekte HbsAg pozitifliği gelişmedi. Ancak biz tüm bebeklerin hepatit serolojilerini, hastaların doğum sonrası takiplere gelme oranı az olduğu ve kontrole gelen hastaların hepsinin de bebeklerin hepatit $B$ serolojilerini test edemediğimiz için değerlendiremedik. Tayvanlı ve Amerikalı 972 çocuğun 10 yıllık takiplerinin yapıldığı bir çalışmada doğumda aşılanan çocukların \%85' inin aşı ile antikor geliştirdiği, sadece üç çocukta 10 yaş civarında kronik hepatit B enfeksiyonu geliştiği bulunmuştur. Bununla birlikte aynı kohortta aşı başarısızlığı gelişen hastalarda kronik hepatit gelişme yaşı 12 aya kadar düşmektedir (17). Bu çalışmada, imuunizasyonun anneden bebeğe bulaş engellemediği durumlarda da kronik hepatit gelişme süresinin uzattığı görülmektedir. Aşı başarısızığının nedenleri olarak intaruterin enfeksiyon, annenin viral yükünün yüksek olması ve HbeAg pozitifliği gösterilmektedir $(6,7,18)$.

Antiviral ajanlar annenin viral yükünü azaltarak, plesental geçişi azalmakta ve intrauterin enfeksiyon oranlarını azaltmayı hedeflemektedir (19). Lamivudin, tenofovir disoproksil fumarat ve telbivudin gebelikte güvenle kullanılabilecek etkin antiviral ajanlardır. Çalışmamızda hastalarımızın 13' ü $(\% 15,3)$ antiviral tedavi aldı. Bunların da 12 ' si $(\% 92,3)$ tenofovir disoproksil fumarat ile, sadece bir hastamı telbivudin ile tedavi edildi. Bir hasta antiviral tedaviyi tolere edemediği için tedaviyi bıraktı ve hastanın takiplerinde HBV DNA değerlerinin bu nedenle $<2000 \mathrm{IU} / \mathrm{mL}$ saptanmadığı tespit edildi. Altı çalışmanın incelendiği, plesebo ile telbivudinin karşılaştırıldığı bir metaanalizde, telbivudinin pleseboya kıyasla viral yükte düşme sağladığı ve yan etki değerlendirmesinde plesebodan farklı olmadığı gösterilmiştir (20). Afrika' da HIV mono enfeksiyonu olan ya da HIV-HBV koenfeksiyonu olan hastalarla yapılan çalışmada, gebelik öncesi ve sırasında tenofovir disoproksil fumarat kullanan gebeler değerlendirilmiş. İki yıllık izlemde erken doğum, konjenital anomaliler, infant renal disfonksiyonu ya da düşük doğum ağırlığı ile tenofovir arasında bir ilişki saptanmamıştır (21). Daha küçük bir grupta yapılan retrospektif bir çalışmada HBV viral yükü yüksek, Hbe Ag pozitif 11 gebe, gebeliğin son trimesterinde tenofovir ile tedavi edilmiş. Gebelerin viral yüklerinin anlamlı oranda düştüğü ve 11 bebeğin 7-9 aylık takiplerinde HbsAg pozitifliği gelişmediği belirlenmiştir (22). Çalışmamızda etkinliği ve güvenilirliği kanıtlanmış antivirallerle hastalarımızı tedavi ettik. Ancak tedavi alan hasta grubumuzun küçük olması ve doğum sonrasında gebelerin ve bebeklerin tamamının takibinin yapılamamış olması nedenleri ile bulduğumuz sonuçlarla genelleme yapmak mümkün görünmemektedir.

Çalışmamızda hastaların HbsAg taraması sayesinde, gebelikte hepatit B virusu ile enfekte olduklarını öğrendiklerini belirledik. Gebelikte HbsAg taramaların yapılması bu hastaların tespiti ve anneden bebeğe bulaşın önlenmesinde çok büyük önem taşımaktadır. Literatürde anne viral yükünün yüksek olması, intrauterin enfeksiyon, mutant suşlarla enfeksiyon olunması ve HbeAg pozitifliği gibi nedenlerle aşı başarısızlıkları bildirilmektedir. Ancak çalışmamızda immunizasyon sonrasında, aşı başarısızlığı saptamadık. Bu durum, takip süresinin kısa olması ve tüm bebeklerin doğum sonrasında takiplerinin yapılamamış olması ile ilişkili olabilir. Vertikal bulaşın önlenebilmesi için gebelik süresince ve sonrasında anne ve bebeklerin yakın takip edilmesi gerektiğini düşünmekteyiz.

\section{Sonuç}

Sunduğumuz çalışmada kronik hepatit B'li anneye gebelik döneminde uygulanan antiviral tedavinin bebeğe zarar vermeksizin vertikal geçişi önlediği gözlendi.

\section{Çıkar çatışması / finansal destek beyanı}

Bu yazıdaki hiçbir yazarın herhangi bir çıkar çatışması yoktur. Yazının herhangi bir finansal desteği yoktur.

\section{Kaynaklar}

1. http://www.who.int/news-room/fact-sheets/detail/hepatitis-b, erişim 01/12/2018.

2. Hyams K. Risk of cronicity following acute hepatitis B virus infection: a review. Clin Infect Dis 1995; 20: 992-1000.

3. Szmuness W, Steven CE, Harley E, Zang E, Oleszko W, William D, Sadovsky $R$ et al. Hepatitis B vaccine: demostration of efficacy in controlled clinical trial in aahigh-risk population in United States. N Engl J Med 1980; 303: 833-41.

4. Francis D, Hadler S, Thompson S, Maynard J, Ostrow D, Altman 
$\mathrm{N}$, Braff $\mathrm{E}$ et al. The preventation of hepatitis B with vaccine. Report of the Centre for Disease Control multi-center efficacy trial among homosexuel men. Ann Intern Med 1982; 97: 362-66.

5. Pan $C Q$, Duan ZP, Bhamidimarri KR, et al. An algorithm for risk assessment and intervention of mother to child transmission of hepatitis B virus. Clin J Gastroenterol Hepatol 2012; 10: 452-59.

6. Stevens CE, Beasley RP, Tsui J et al. Vertical transmission of hepatitis B antigen in Taiwan. N Engl J Med 1975; 292:771-4.

7. Ngui SL, O'Connell S, Eglin RP et al. Low detection rate and maternal provenance of hepatitis $B$ virus $S$ gene mutants in cases of failed postnatal immunoprophylaxis in England and Wales. J Infect Dis 1997; 176:1360-65.

8. Han G-R, Cao M-K, Zhao W et al. A prospective and open label study for the efficacy and safety of telbivudine in pregnancy for the prevention of perinatal transmission of hepatitis $B$ virus infection. J Hepatology 2011; 55: 1215-21.

9. Han GR, Xu CL, ZhaoW, Yang YF. Management of chronic hepatitis B in pregnancy. World J Gastroenterol 2012; 18: 4517-21.

10. Pan $C Q$, Han $G R$, Jiang $H X$ et al. Telbivudine prevents vertical transmission from $\mathrm{HBeAg}$-positive women with chronic hepatitis B. Clin Gastroenterol 2012; 10:520-6.

11. Terrault NA, Bzowej NH, Chang KM et al. AASLD practice guidelines for the treatment of hepatitis B. Hepatology 2016; 63: 261-83.

12. Tram TT. Hepatitis B in pregnancy. CID 2016; 62:314-17.

13. Terrault NA, Bzowej NH, Chang KM et al. AASLD practice guidelines for the treatment of hepatitis B. Hepatology 2016; 63: 261-83.

14. Toy $M$, Onder FO, Wörmann $T$ et al. Age- and region-specific hepatitis $B$ prevalence in Turkey estimated using generalized linear mixed models: A systematic review. BMC Infect Dis 2011; 12: 337.
15. Hamdani-Belghiti S, Bouazzaou NL. Mother-child transmission of hepatitis B virus. State of the problem and prevention. Arch Pediatr 2000; 7: 879-882.

16. Shi Z, Yang Y, Wang $\mathrm{H}$ et al. Breastfeeding of newborns by mothers carrying hepatitis $B$ virus: A meta-analysis and systematic review. Arch Pediatr Adolesc Med 2011; 165: 837-46.

17. Wu J, Hwang L, Goodman K, Beasley R. Hepatitis B vaccination in high-risk infants: 10 year follow-up. J Infect Dis 199; 179:1319-25.

18. Saho Z, Zhang L, Xu J, Xu D, Men K, Zhang J, Cui H et al. Motherto-infant transmission of hepatitis $B$ virus: a Chinese experience. J Med Virol 2011; 83: 791-5.

19. Shi Z, Li X, Ma L, yang Y. Hepatitis B immunglobulin injection in pregnancy to interrupt hepatitis $B$ virus mother-to-child transmission - a meta-analysis. Int J Infect Dis 2010; 14: 622-34.

20. Deng M, Zhou X, Gao S, Yang S, Wang B, Chen H, Ruan B. The effects of telbivudine in late pregnancy to prevent intarauterine transmission of the hepatitis B virus: a systematic review and meta-analysis. Virol J 2012; 9: 185.

21. Gibb D, Kizito H, Russell E, Chidziva E, Zalwango E, Nalumeya $\mathrm{R}$, Spyer $\mathrm{M}$ et al. Pregnancy and infant outcome among HIVinfected taking long-term ART with and without tenofovir in DART trail. PloS Med 2012; 9: e1001217.

22. Pan C, Mi L, Bunchorntavakul C, Karsdon J, Huang W, Singhvi G, Ghany $\mathrm{M}$ et al. Tenofovir disoproroxil fumarate for prevention of vertical transmission of hepatitis $B$ virus infection by highly viremic pregnant women: a case series. Dig Dis Sci 2012; 57: 2423-29. 